\title{
Samsāra and Karman in the Early Context
}

It is beyond doubt that Jainism incorporated a belief in rebirth and karmic retribution from the beginning. What is more, it seems safe to claim that Jainism, right from the beginning, presented itself as a way to escape from the cycle of rebirths (samsāra) and karmic retribution. Judging by the practices that we find prescribed already in our earliest sources, karmic retribution and the proposed liberation (mokssa) from it were envisaged in the following manner.

Jainism's path to liberation culminates in the total immobilization of body and mind. Indeed, this final immobilization ends in the physical death of the aspirant for liberation, and in his (or also her, according to some) liberation from rebirth and karmic retribution. This makes sense on the assumption that all activity has consequences in future lives. Only thus is the cessation of all activity a necessary condition for liberation from karmic retribution. Early Buddhist literature confirms that in Jainism all activity has karmic consequences, and a detailed study of the earliest texts of the Śvetāmbara canon - including the Ācārāniga Sūtra and the Sūtrakrtāinga Sūtraconfirms that passions and the like are to be avoided for no other reason than that they lead to activity. ${ }^{1}$

There is little more regarding karmic retribution that we can safely attribute to the earliest Jainism: all activity leads to karmic retribution, which is always depicted negatively. The texts "never promise an auspicious next birth to the person leading a good life." 2 This explains no doubt why, still in more recent days, stories about earlier lives of the Jina, fewer in number than those concerning the Buddha in Buddhism, do not, unlike their Buddhist counterparts, emphasize the good deeds that allowed these earlier incarnations to reach this highest state; ${ }^{3}$ this is in spite of the fact that some late and post-canonical texts know a kind of karman - called tīrthaíkaranāmakarman (name karman of a Tīrthankkara) - that accumulates in future Tìrthankaras. ${ }^{4}$ The only way to avoid the negative consequences of one's activity is through total immobilization until death, both physical and mental.

The logic of this scheme is impeccable but left its early followers with a problem. It has as consequence that a liberated person is a dead person, implying that there can be no liberated teacher of the Jain path because attaining enlightenment or omniscience would be virtually simultaneous with death and liberation. Even Mahāvīra, the most recent Tīrthankkara, was by this logic no enlightened person, nor were any of the earlier Tīrthankaras.

To my knowledge, there is no explicit discussion of this issue that goes back to the earliest time. However, we do find that Jainism developed an elaborate theoretical structure around the notion of karmic retribution that did provide an answer to this question. This new structure finds its earliest expression in certain texts of the Śvetāmbara canon - beginning, perhaps, with the Vyākhyāprajñapti Sūtra and is subsequently systematized in the Tattvārtha Sütra and other texts. Also the Satkhandāgama, one of the texts that the Digambaras look on as canonical, deals with the new vision of karman, as do many more recent works. In all of them, karman is presented as a form of matter that clings to the $\operatorname{soul}(j \bar{i} v a)$ and that is responsible for the soul's being caught up in samsāra. We will see below what place this new understanding of karman reserves for liberated persons.

S. Ohira ${ }^{5}$ has drawn attention to the fact that the material conception of karman could not have arisen until other developments, most notably an atomic theory associated with the term pudgala (which came to designate matter), had come into being. What is more, the notion of karman as a substance that clings to the soul only makes sense once the classical Jain idea of a soul that is coextensive with the body (śarira) has been accepted. These notions (pudgala, body-sized soul) entered Jainism under the influence of Abhidharma Buddhism. ${ }^{6}$ The particular kind of Abhidharma that exerted

\footnotetext{
4 Jaini, 1981, 114.

5 1980, 44-45.

6 see Bronkhorst, 200o; 2016a.
} 
this influence arose in northwest India, in the 2nd century BCE at the earliest. ${ }^{7}$ It is possible, but not certain, that the new understanding of karman came about at the time when many other aspects of Jainism underwent a major overhaul (including the abandonment of relic and stūpa worship), presumably under the Kushanas during the early centuries of the Common Era.

What did the new karman doctrine look like? The earliest Jainism linked karmic retribution to all activity whatsoever, not only to moral and immoral activity. Only thus did it make sense to look for a way out through total bodily and mental immobilization. In the form of Jainism that subsequently arose, activity carries the name yoga. The activity (yoga) of the soul is responsible for the influx (assrava) of karmic matter, more precisely perhaps, the influx of matter that then becomes karmic matter of various kinds. In this respect, scholastic Jainism builds on and develops its old tradition. However, a new element is added: karmic matter clings to the soul as a result of passion (kașāya). This element, passion, introduces a psychological dimension that was, as far as we can tell, missing as a causal factor in the earliest Jainism. If it is indeed a new dimension, it is not difficult to guess where it came from. A preoccupation with psychological processes had characterized Buddhism from its beginning. It was under the influence of Buddhism that Jainism underwent major changes. It makes sense to assume that it was also under the influence of Buddhism that Jainism introduced the psychological dimension responsible for entities like passion.

The Jain path to liberation now becomes a path of purification. ${ }^{9}$ The soul has to be purified of the karman that clings to it. As it so happens, karmic matter falls into two general categories, depending on whether the person concerned has passions (kașāya) or not: karman relating to future lives (sāmparāyika) and karman relating to the path of asceticism (iryāpatha). ${ }^{10}$ In the former case, the influx of karman causes rebirth; in the latter, the influx of karman is of short duration (it does not cling) and does not cause rebirth. It will be clear that in this way the system has a place for people who act in the world without having to pay for it in a future rebirth. In other words, there is now place for Tīrthan்karas and kevalins. Strictly speaking, they are enlightened but not yet liberated. P. Dundas describes the situation as follows:

Spiritual deliverance (mokșa) is defined in simple terms by Umāsvāti (TS 10.5) as release from all karma. This should in its finality be clearly distinguished from the attainment of enlightenment which, after the cultivation of morally positive attitudes, the practice of austerity and the gradual suppression of negative discriminative mental processes, involves the uprooting of deluding karma which is then succeeded by the removal of the remaining three harming karmas, thus liberating the innate qualities, such as omniscience, of the jiv $a$. Enlightenment, however, does not of itself entail death, for the operation of the four non-harming karmas is still unimpaired, with life and name karma guaranteeing the continuation of embodied existence and experience karma ensuring bodily sensations, although the latter point was a source of sectarian dispute for the Digambaras who denied that a kevalin's feeling karma could bring about an effect such as hunger. The enlightened person, whether fordmaker or kevalin, may therefore spend a considerable period after enlightenment engaging in mental and physical activities such as walking, preaching and meditation. However, no new karma is bound by these activities nor is it possible in this state to carry out acts of violence, even involuntarily.11

There is a condition to reaching enlightenment: Tìrthankaras and kevalins have to be without passions (kașāya). How is that to be accomplished? Clearly, the path to liberation now passes through the suppression of kașāya. Unfortunately, it appears that the Jain scholiasts had some difficulty categorizing kașāya in their scheme of things. This is confirmed by looking at the Tattvārtha Sūtra, a text whose "greatest achievement...lies in its systematization of the philosophical contents of the Jaina canon...and in its innovation of certain traditional concepts as well as the formulation of certain new concepts."12 The Tattvārtha Sūtra includes the kașāya (of which it distinguishes four subtypes [see below]) in the wider category of "right-conduct deluding karmas" (cāritramohanīya). ${ }^{13}$ This means that kașāya itself has become a form of karman,
7 Bronkhorst, 2016b, § III.3.2.

8 for brief presentations, see Glasenapp, 1942; Jaini, 1979, 111ff.; Dundas, 2002, 97ff.; for the canonical evidence, see Schubring, 2000, 172ff.

9 see Jaini, 1979.

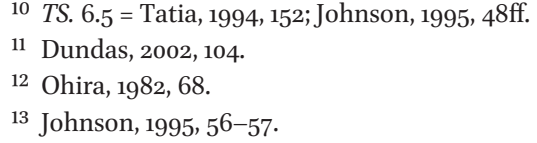

10 TS. 6.5 = Tatia, 1994, 152; Johnson, 1995, 48ff.

12 Ohira, 1982, 68 
thus turning the explanation of the influx of rebirthproducing karman into a circular affair: karman is responsible for the fact that karman clings to the soul. R.J. Zydenbos ${ }^{14}$ calls kașāya "a kind of 'masterkarma' through which other kinds of karma are bound."

Whatever the precise method to be used, once a person has succeeded in eliminating kașāya and with it the various forms of karman relating to future lives (sāmparāyika), he or she can still engage in activity (yoga), but this will only lead to the influx (assrava) of karman relating to the path of asceticism (iryāpatha), which will disappear again after a very short time. Those who do not succeed in eliminating kașāya will be reborn as a result of the karman that remains. It is here to be noted that the karmic particles that attach to nonliberated souls form the karmic body (kärmañaśarìra), which along with the luminous body (taijasaśarìra) accompanies the soul from one birth to the next. ${ }^{15}$ This assures that none of the karmic burden is lost during transmigration.

It should be clear from the above that the position adopted by Jain scholiasts crucially accepted the idea that the soul can act, that it can have activity (yoga), but not all activity has karmic consequences. In its most generally accepted version, at least from the Tattvārtha Sütra onward, only activity accompanied by passion (kasāya) had such effects. However, this was not the only possible version, and a highly respected thinker of uncertain date, Kundakunda, proposed a different one. I will concentrate on his Samayasāra, a work that "has greatly influenced Digambara thinking for centuries, and has been acclaimed by them as the most profound exposition of the Jaina doctrine."16

Kundakunda draws inspiration from the Brahmanical Sāṃkhya philosophy. This philosophy introduces a distinction between two altogether different realms: the self (purusa) and nature (prakrti). The self is completely inactive, and all activity takes place in the realm of nature. Sāmphya teaches that the way to liberation passes through the realization that one's inner self is altogether different from all that acts.

Kundakunda disagrees in claiming that the soul, unlike the self of Sāmphya, can and does act.
However, he agrees with Sāmkhya in thinking that liberation depends on the realization that the soul is altogether different from acts that have karmic consequences. The soul is active in that it produces bhāvas, "states" such as anger (krodha), as a result of which karmic matter may cling to the soul. From a practical, and therefore lower, point of view, the soul is the agent of material karman, but from the highest point of view, it is the agent of the bhāvas only, not of material karman. Only metaphorically can one say that karman has been produced by the soul.

The following verses from the Samayasāra illustrate these points:

If the soul did not undergo modifications under the influence of bhāvas such as anger, there would be no cycle of rebirths (samsāra) or the Sāmphya philosophy would be correct. ${ }^{17}$

The soul makes a bhāva and is its agent from the highest point of view,

while from a practical (and therefore lower) point of view, it is the agent of material karman. ${ }^{18}$

The soul is an agent by its own bhāva, but it is not the agent of all the bhāvas produced by material karman. ${ }^{19}$

Just as the self makes its own bhāva (ätmanah bhāvam) because of material karman,

so it experiences its own bhāva because of material karman. ${ }^{20}$

Kundakunda's crucial point is that not all bhāvas result in karmic matter clinging to the soul. Some bhāvas do no such thing. If the soul engages only in activities that produce such harmless bhāvas, then there will be no further influx of karman.

The picture is somewhat complicated by the fact that in Kundakunda's opinion, there are two kinds of bhāvas: those that belong to and are (part of) the soul and those that belong to karman. Kundakunda's main argument turns around bhävas that are part of the soul. These are the bhāvas that the soul produces, and it is by producing harmless bhāvas from among these that the soul can reach liberation.

A comparison of Kundakunda's understanding with the classical picture depicted above shows a number of similarities along with certain

\footnotetext{
141983,15 .

15 Jaini, 1980, 132.

${ }_{16}$ Jaini, 2000, 30; 2001, 92; for an analysis of Kundakunda's thought, see Bronkhorst, 2016c.

17 SS. 127; trans. by author.
}

18 SS. 24; trans. by author.
${ }_{19}$ SS. 88; trans. by author.
20 SS. 93; trans. by author. 
differences. Kundakunda's bhāvas specified as anger and so on correspond to kașāya in the Tattvārtha Sūtra and elsewhere. Indeed, kașāya is there said to cover anger (krodha), pride (māna), deceit (māyā), and greed (lobha). There is, however, a major difference. Kașāya, on the one hand, is ultimately a form of karman; Kundakunda's bhāvas (or at least the relevant ones), on the other hand, are part of the soul. What is more, in Kundakunda's scheme, the soul must acquire an insight into the highest point of view, according to which it is never the agent of material karman. From the highest standpoint, the self makes nothing butitself and experiences itself.It is through ignorance that the soul thinks it becomes the agent of the karmans; in reality, it is not.

With this insight, the soul can see which is the road leading to liberation. By concentrating on only those states (bhāvas) that have no karmic consequences, karman will no longer cling to it, and purification of the soul can be accomplished.

\section{Bibliography}

Appleton, N., Narrating Karma and Rebirth: Buddhist and Jain Multi-Life Stories, Cambridge UK, 2014.

Bronkhorst, J., "Abhidharma and Indian Thinking," in: B. Dessein \& W. Teng, eds., Text, History, and Philosophy: Abhidharma across Buddhist Scholastic Traditions, BIL 50, Leiden, 2016a, 29-46.

Bronkhorst, J., How the Brahmins Won: From Alexander to the Guptas, $\mathrm{HdO}$ 2/30, Leiden, 2016b.

Bronkhorst, J., "Kundakunda versus Sāṃkhya on the Soul," in: C.K. Chapple, ed., Yoga in Jainism, London, 2016c, 37-47.

Bronkhorst, J., "Abhidharma and Jainism," in: Abhidharma and Indian Thought: Essays in Honor of Professor Doctor Junsho Kato on His Sixtieth Birthday, publ. Committee for the Felicitation of Professor Doctor Junsho Kato's Sixtieth Birthday, Nagoya, Tokyo, 2000, 598-581 (13-30).

Dixit, K.K., Early Jainism, Ahmedabad, 1978.
Dundas, P., The Jains, London, ${ }^{2} 2002$.

Glasenapp, H. von, Die Lehre vom Karman in der Philosophie der Jainas. Nach den Karmagranthas dargestellt, Leipzig, 1915; ET: G.B. Gifford, Doctrine of Karman in Jain Philosophy, Bombay, 1942, repr. 1991.

Jaini, P.S., Collected Papers on Jaina Studies, New Delhi, 2000. Jaini, P.S., "Tīrthankkara-prakṛti and the Bodhisattva Path," JPTS 9, 1981, 96-104; repr. in: P.S. Jaini, Collected Papers on Jaina Studies, New Delhi, 2000, 111-119.

Jaini, P.S., "Karma and the Problem of Rebirth in Jainism," in: W. O'Flaherty, ed., Karma and Rebirth in Classical Indian Traditions, Berkeley, 1980, 217-238; repr. in: P.S. Jaini, Collected Papers on Jaina Studies, New Delhi, 2000, 121-145; repr. in: J. Soni, ed., Vasantagauravam: Essays in Jainism Felicitating Professor M.D. Vasantha Raj of Mysore on the Occasion of His Seventy-fifth Birthday, Mumbai, 2001, $85^{-98 .}$

Jaini, P.S., The Jaina Path of Purification, New Delhi, 1979.

Jaini, P.S., "The Jainas and the Western Scholar," Sambodhi 5/2-3, 1976, 121-131; repr. "The Jainas and the Western Scholar," in: P.S. Jaini, Collected Papers on Jaina Studies, New Delhi, 200o, 121-145; repr. in: Soni, J., ed., Vasantagauravam: Essays in Jainism Felicitating Professor M.D. Vasantha Raj of Mysore on the Occasion of His Seventy-fifth Birthday, Mumbai, 2001, 85-98.

Johnson, W.J., Harmless Souls: Karmic Bondage and Religious Change in Early Jainism with Special Reference to Umāsvāti and Kundakunda, LSLJRS 9, New Delhi, 1995.

Ohira, S., A Study of Tattvārtha Sūtra with Bhāsya, with Special Reference to Authorship and Date, LDS 86, Ahmedabad, 1982.

Ohira, S., "Problems of the Pūrva," JJ 15, 1980, 41-55.

Schubring, W., The Doctrine of the Jainas Described after the Old Sources, New Delhi, 2000.

Tatia, N., trans., Tattvārtha Sūtra: That Which Is: Umāsvāti/ Umāsvāmī with the Combined Commentaries of Umāsvāti/ Umāsvāmī, Pūjyapāda and Siddhasenagaṇi, San Francisco, 1994.

Zydenbos, R.J., Mokșa in Jainism, according to Umāsvāti, BASF 83 , Wiesbaden, 1983.

JOHANNES BRONKHORST 